\title{
EFFECT OF FRICTION STIR WELDING ON MECHANICAL PROPERTIES OF DISSIMILAR WELD JOINTS
}

\author{
G.Rajyalakshmi ${ }^{1}$, Md.Aslam ${ }^{2}$ \\ 1 School of Mechanical and Building Sciences/VIT University, Vellore, India \\ 2 School of Mechanical and Building Sciences/VIT University, Vellore, India
}

\begin{abstract}
Friction stir welding (FSW) is a novel solid state welding process for joining metallic alloys and has emerged as an alternative technology used in high strength alloys that are difficult to join with conventional techniques. The applications of FSW process are found in several industries such as aerospace, rail, automotive and marine industries for joining aluminum, magnesium and copper alloys. The FSW process parameters such as rotational speed, welding speed, axial force and attack angle play vital roles in the analysis of weld quality. The aim of this research study is to investigate the effects of different welding speeds and tool pin profiles on the weld quality of AA6082-Al 5083. This material has gathered wide acceptance in the fabrication of light weight structures requiring a high strength-to-weight ratio. Circular and squared pin are used as tool pin profiles in this research. The appearance of the weld is well and no obvious defect is found using these tools. Consequently, the obtained results explain the variation of stress as a function of strain and the effect of different welding speed and pin profiles on yield strength ultimate tensile strength and elongation.
\end{abstract}

Keywords: Friction Stir Welding, AA6082- Al 5083 aluminum alloy, Tool pin profiles, Welding speed, Mechanical Properties.

\section{INTRODUCTION}

Friction stir welding (FSW) is a new solid state welding process, where the weld is produced by softening, plastic deformation combined with forging action caused by tool rotation of base metal (Fig. 1) [1-3]. Absence of melting of base metal in FSW reduces oxidation, residual stress, solidification related defects. The microstructure of the weld generally shows a central weld nugget with onion ring structure, a thermo-mechanically affected zone (TMAZ) close to the nugget, and a very small heat affected zone (HAZ) [4]. Recently many reports on friction stir welding of various metal system such as aluminum
[5-10], magnesium [11-12], mild steel [13], stainless steel [14], and dissimilar systems such as aluminum to stainless steel [15], aluminum to steel [16], aluminum to copper [17], aluminum to magnesium [18], have been published. Preliminary studies on the FSW for copper to copper [19-21] and brass [22-23] have also been reported. This solid state process leads to minimal microstructural changes and better mechanical properties than conventional welding $[24,25]$ (Nicholas et al., 2002; Ericsson et al., 2003; Ellis et al., 1996). The process was developed initially for aluminum alloys, but since then, FSW was found suitable for joining a large number of materials. Conventional fusion 
welding of aluminum alloys often produces a weld which suffers from defects, such as porosity developed as a consequence of entrapped gas not being able to escape from the weld pool during solidification. In contrast, with FSW, the interaction of a nonconsumable tool rotating and traversing along the joint line creates a welded joint through visco plastic deformation and consequent heat dissipation resulting in temperatures below the melting temperature of the materials being joined. Other interesting benefits of FSW compared to fusion processes are low distortion, excellent mechanical properties in the weld zone, execution without a shielding gas, and suitability to weld all aluminum alloys[26] (Mishra \& Mahoney, 2007). Some authors analyzed the influence of the tool rotation speed [27-28] welding speed [29, 30, $31,32]$ and both parameters simultaneously on the microstructure and mechanical properties of 6XXX welds [33, 34] Recently, experimental work has been carried out for welding of tube to tube plate by using FSW process and it is also investigated numerically [35] .These works enhance the difficulty in evaluating the dependence of the thermal and mechanical properties on weld parameters. In this investigation, an attempt has been made to understand the effect of tool pin profiles and different welding speed on the weld quality of AA6082- Al 5083 using FSW process. Circular and squared thread pin are used as tool pin profiles in this research. The pin travelled longitudinally at different welding speed $(\mathrm{mm} / \mathrm{min})$ and constant feed was held at $20 \mathrm{~mm} / \mathrm{min}$ in all of the experiments. Consequently, the appearance of the weld for different welding speed has been examined by using radiography technique and the impact of the stress as a function of strain and the effect of different welding speed and pin profiles on tensile strength and elongation are analyzed.

\section{FRICTION STIR WELDING PROCESS}

FSW is produced by rotating and plunging a specially-designed cylindrical, shouldered tool with a small diameter pin into the joint line between two butted plates. Frictional heat causes the metal to soften and allows the tool to traverse along the joint line. The FSW process is divided in two famous processes defined as lap joints and butt joints. In this research, the process of butt joints is investigated. The two plates are clamped on a rigid back plate. The fixturing prevents the plates from spreading apart or lifting during welding. The welding tool, consisting of a shank, shoulder and pin, is then rotated to a prescribed speed. The tool is slowly plunged into the work piece material at the butt line, until the shoulder of the tool forcibly contacts the upper surface of the material and the pin is a short distance from the back plate. A downward force is applied to maintain the contact and a short dwell time is observed to allow for the development of the thermal fields for preheating and softening the material along the joint line. At this point, a lateral force is applied in the direction of welding (travel direction) and the tool is forcibly traversed along the butt line until it reaches the end of the weld. Alternately, the plates could be moved while the rotating tool remains stationary. Upon reaching the end of the weld, the tool is withdrawn while it is still being rotated. As the pin is withdrawn, it leaves a keyhole at the end of the weld. The FSW process of butt joints is shown in Fig. 1. [3].

FSW process generates three distinct microstructural zones shown in Figure 2, A-the nugget zone, B-the thermo-mechanically affected zone (TMAZ) and C- the heat 


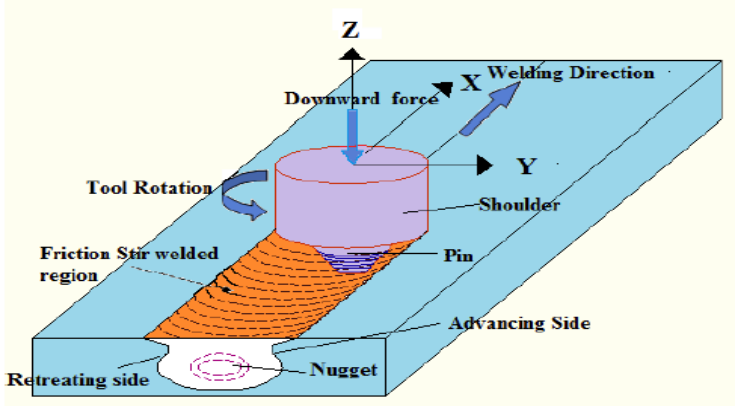

Fig. 1. Friction stirs welding process

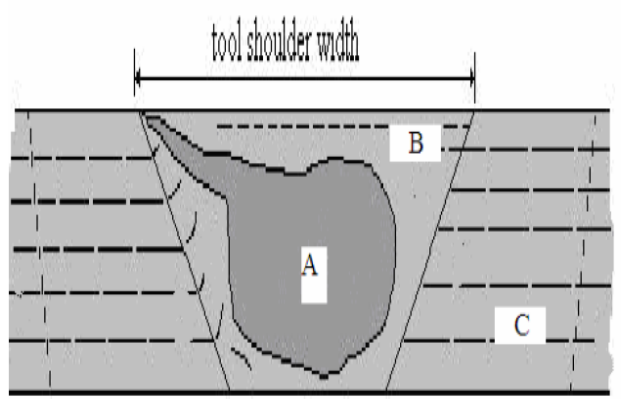

Fig 2. Macrostructural Features of Friction Stir Welds

affected zone (HAZ). The nugget is the region through which the tool piece pin passes, and thus experiences high deformation and high heat. It generally consists of fine equiaxed rains due to full recrystallization. The TMAZ adjacent to the nugget is the region where the metal is plastically deformed as well as heated, but this is not sufficient to cause recrystallization. The HAZ experiences only a heating effect, with no mechanical deformation.

\section{EXPERIMENTAL WORK}

The friction stir welds have been carried out by using a properly designed clamping fixture that allows the user to fix the two sheets $(160 \mathrm{~mm} \times 60 \mathrm{~mm})$ with the rolled plate of $5 \mathrm{~mm}$ thickness to be butt welded on a CNC vertical milling machine. Fig. 3. shows the vertical $\mathrm{CNC}$ milling machine used for experimental work.

In this investigation, the base materials, AA6082-AA5083, which is a precipitation hardened aluminum alloy widely used in

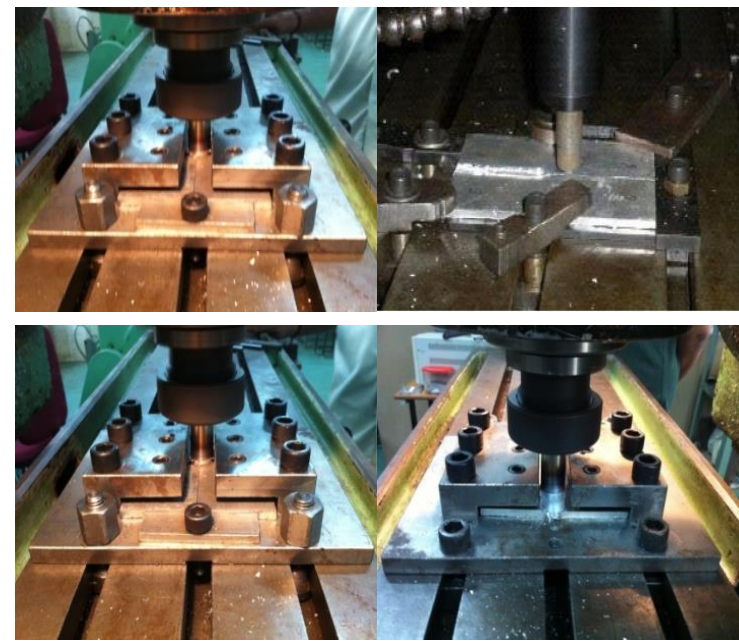

Fig. 3. Experimental Setup

aerospace applications due to its high strength was used. FSW plates were examined using Xray radiography. There was no apparent defect in welded plates. The chemical compositions of AA5083and AA6082 are shown in Table 1 and Table 2, respectively.

TABLE 1: CHEMICAL COMPOSITION OF AA5083

\begin{tabular}{|l|l|l|l|l|l|l|l|l|l|}
\hline Element & $\mathrm{Si}$ & $\mathrm{Fe}$ & $\mathrm{Cu}$ & $\mathrm{Mn}$ & $\mathrm{Mg}$ & $\mathrm{Zn}$ & $\mathrm{Ti}$ & $\mathrm{Cr}$ & $\mathrm{Al}$ \\
\hline \%present & 0.4 & 0.4 & 0.1 & $\begin{array}{l}0.4- \\
1.0\end{array}$ & $\begin{array}{l}4.0- \\
4.9\end{array}$ & 0.25 & 0.15 & $\begin{array}{l}0.05- \\
0.25\end{array}$ & Balance \\
\hline
\end{tabular}

TABLE 2: CHEMICAL COMPOSITION OF AA6082

\begin{tabular}{|l|l|l|l|l|l|l|l|l|l|}
\hline Element & $\mathrm{Si}$ & $\mathrm{Fe}$ & $\mathrm{Cu}$ & $\mathrm{Mn}$ & $\mathrm{Mg}$ & $\mathrm{Zn}$ & $\mathrm{Ti}$ & $\mathrm{Cr}$ & $\mathrm{Al}$ \\
\hline \%present & $0.7-$ & $<$ & $<$ & $0.4-$ & $0.6-$ & $<$ & $<$ & $<$ & Balance \\
& 1.3 & 0.5 & 0.1 & 1.0 & 1.2 & 0.2 & 0.1 & 0.25 & \\
\hline
\end{tabular}

\subsection{Configuration OF Welding ToOL GEOMETRY}

The tool material has been selected as $\mathrm{H}-13$ tool steel. -type tool steels were developed for strength and hardness during prolonged exposure to elevated temperatures. All of these tool steels use a substantial amount of carbide forming alloys. H13 has high hardenability, excellent wear resistance, hot toughness, good thermal shock resistance and will tolerate some water cooling in service. 

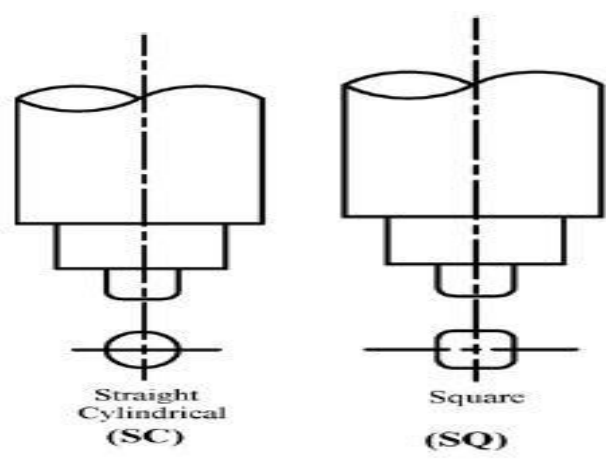

Fig.4. Image of the tool pin profiles

\subsection{WELDING PARAMETERS AND TOOL DIMENSIONS}

The initial joint configuration was obtained by securing the plates in position using mechanical clamps. The direction of welding was normal to the rolling direction. Single pass welding procedure was used to fabricate the joints. The welding parameters used to fabricate the joints are presented in Table 4. The chemical composition of the tool is shown in Table 3

TABLE 3: CHEMICAL COMPOSITION OF TOOLS

\begin{tabular}{|l|l|}
\hline Element & \%Present \\
\hline $\mathrm{C}$ & $0.32-0.45 \%$, \\
\hline $\mathrm{Mn}$ & $0.20-0.50 \%$, \\
\hline $\mathrm{Si}$ & $0.18-0.20 \%$ \\
\hline $\mathrm{Cr}$ & $4.75-5.50 \%$, \\
\hline $\mathrm{Ni}$ & $0.3 \%$, \\
\hline $\mathrm{Mo}$ & $1.10-1.75 \%$, \\
\hline $\mathrm{V}$ & $0.80-1.20 \%$, \\
\hline $\mathrm{Cu}$ & $0.25 \%$, \\
\hline $\mathrm{Ph}$ & $0.3 \%$ \\
\hline $\mathrm{S}$ & $0.3 \%$ \\
\hline
\end{tabular}

TABLE 4: WELDING PARAMETERS AND TOOL DIMENSIONS

\begin{tabular}{|l|l|}
\hline Rotating Speeds(rpm) & $710,1000,1400$ \\
\hline Feed $(\mathrm{mm} / \mathrm{min})$ & 20 \\
\hline Pin length $(\mathrm{mmm})$ & 5 \\
\hline Tool Shoulder diameter $(\mathrm{mm})$ & 18 \\
\hline
\end{tabular}

\section{III.3. SPECIMEN PREPARATION FOR TENSILE} TESTING

To determine the tensile strength of the stir zone, tensile test specimens were sectioned in the longitudinal direction along the weld line with an wire electrical discharge machine (WEDM).Surfaces were prepared by standard

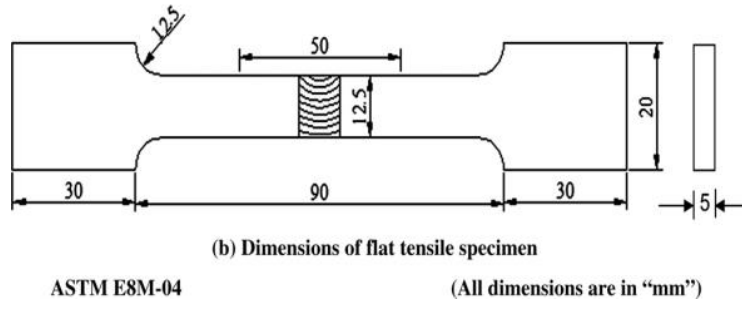

Fig.5. Dimensions of the Tensile test Specimen

metallographic techniques and etched with Keller's reagent. The tensile properties and fracture locations depend mainly on the welding defects and hardness of the joint. When the joints are free from defects, their tensile properties are controlled by hardness and fracture occurred in the heat affected zone (HAZ) on the side that show minimum hardness

\section{RESULTS AND DISCUSSION}

\subsection{NON DESTRUCTIVE TESTING}

Non-Destructive test is carried out on all the welded specimens by Liquid Penetrant Testing method and Radiographic testing and the welds were found to be clean without any cracks and surface defects.

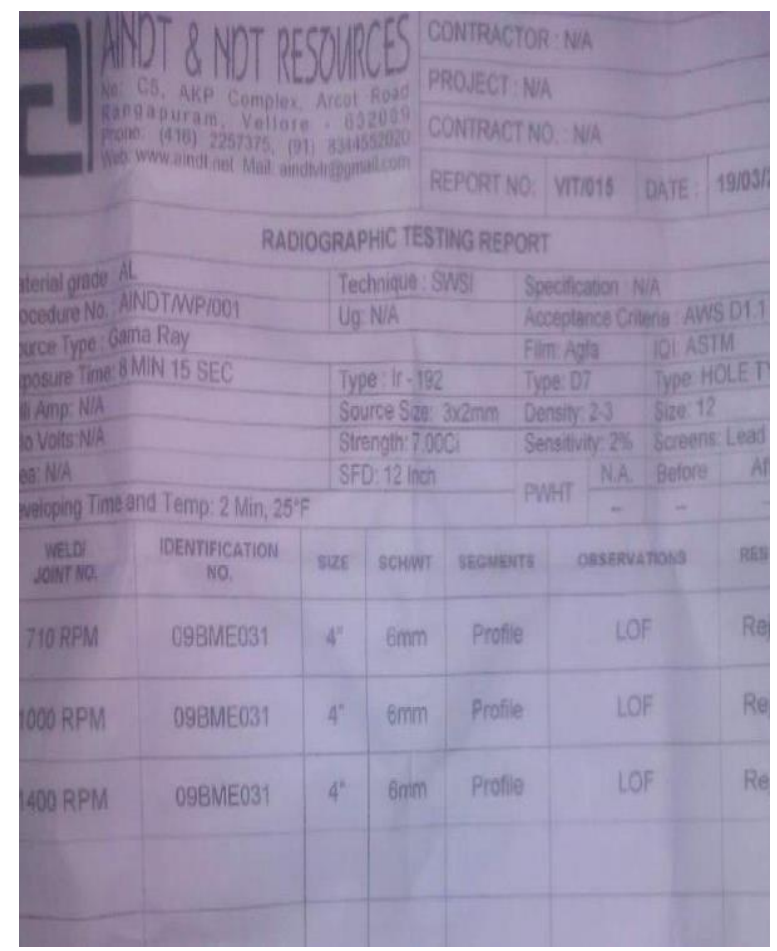

Fig. 6. Results of Non Destructive Testing 


\subsection{MicroStructures}

Microstructures of parent materials and welds were examined by optical microscope. In the base metal, the grain size is not uniformed. Namely, non-equiaxed large grains are over $100 \mu \mathrm{m}$ in size. In contrast, the stir zone is composed of smaller and equiaxed grains.

This result suggests that the stir zone is severely plastically deformed by mechanical stirring action of the rotating probe during the FSW process, and then grain refinement occurs as a consequence of dynamic recrystallization. The grain size, however, increases with the tool rotation speed. Here we observe that the grain size increases in spite of the increase in the tool rotation speed, which is expected to lead to the increase in the strain and strain rate. We also observe that some additional static grain growth occurred in the SZ during cooling after severely plastically deformed by the rotating probe, because the maximum temperature of the $\mathrm{SZ}$ increased with the increase of tool rotation speed. The stir zone (SZ) appears as an ellipse type and onion rings pattern, which is observed in the SZ, was formed by the process of friction heat owing to the rotation of the tool and the forward movement extrudes the metal around to the retreating side of the tool.

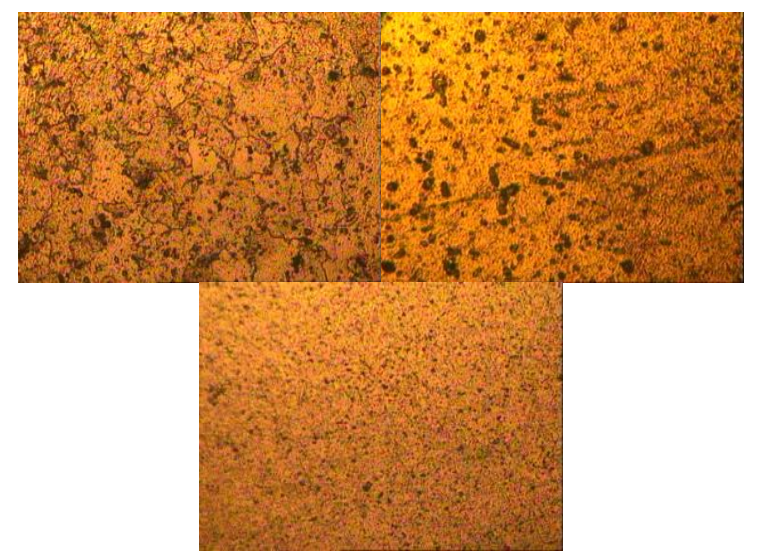

Fig. 7. Optical microstructures of the stir zone (SZ) with various rotating speeds

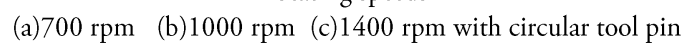

The central part of the weld zone (along the tool centerline) is observed to be dynamically re-crystallized. This is typical of all friction stir welding processes examined in dissimilar metal systems. Typical micrographs showing the dispersion of second-phase in both alloys are in Fig. 8. Particles of several inter-metallic phases are present in the alloys. The majority of the particles are phases containing the usual impurities of $\mathrm{Al}$, i.e., $\mathrm{Fe}$ and $\mathrm{Si}$ and the alloying elements $\mathrm{Mg}, \mathrm{Mn}, \mathrm{Zn}, \mathrm{Si}$. The phases $\alpha$-Al12 (Fe, Mn) 3Si, Al6 (Fe, Mn) and $\mathrm{Mg} 2 \mathrm{Si}$ are present in AA5083 sheets. The alloy AA6082 contains phases containing Fe, $\mathrm{Si}$ and $\mathrm{Cu}$, i.e. $\mathrm{Al} 7 \mathrm{Cu} 2 \mathrm{Fe}$, and also the phases $\mathrm{Al} 2 \mathrm{CuMg}, \mathrm{Mg} 2 \mathrm{Si}$ and $(\mathrm{Zn}, \mathrm{Cu}, \mathrm{Al}) 2 \mathrm{Mg}$.

As a result, the process of FSW does not affect the shape and size of these particles. While FSW does not affect inter-metallic particles, the stirring and heating of the material from both sides of joining line significantly changes the features of grain structureThree zones with different microstructure and properties can be distinguished: a) nugget; b) thermomechanically affected zone (TMAZ); c) heat affected zone (HAZ).

\subsection{Tensile Test}

It was observed that the influences of the tool rotation speed on the tensile strength and elongation of the friction stir welded plates.

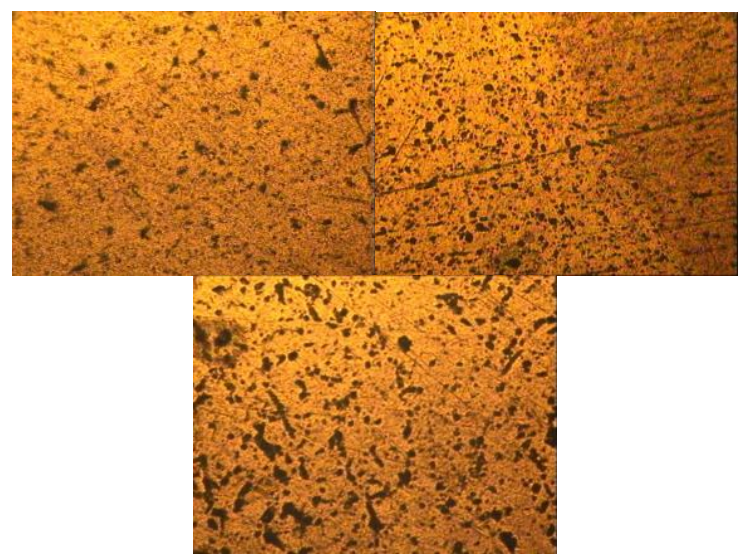

Fig. 8. Optical microstructures of the stir zone (SZ) with various rotating speeds

(a) $700 \mathrm{rpm} \quad$ (b) $1000 \mathrm{rpm}$ (c) $1400 \mathrm{rpm}$ with square tool pin 
For the friction stir welded plates, a maximum tensile strength of about $217 \mathrm{MPa}$ was obtained at the tool rotation speed of 1000 rpm, which was about $66 \%$ of the tensile strength of the base metals. The samples showed very low elongation of $3 \%$ or less. The elongation did not significantly change as a function of the tool rotation speed; although a maximum elongation of about $3 \%$ was obtained at $1000 \mathrm{rpm}$.

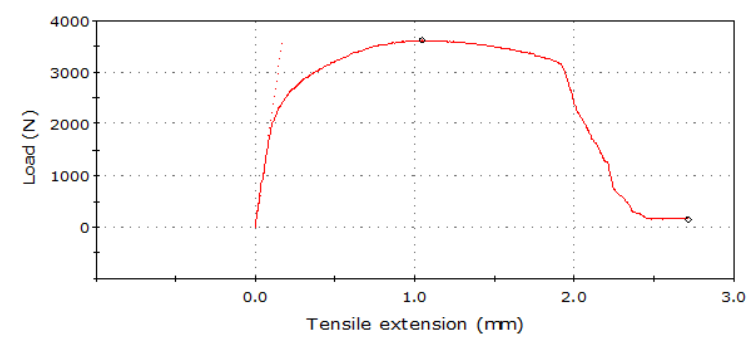

Fig.9. Engineering stress-strain diagram of circular pin profile for $1400 \mathrm{rpm}$

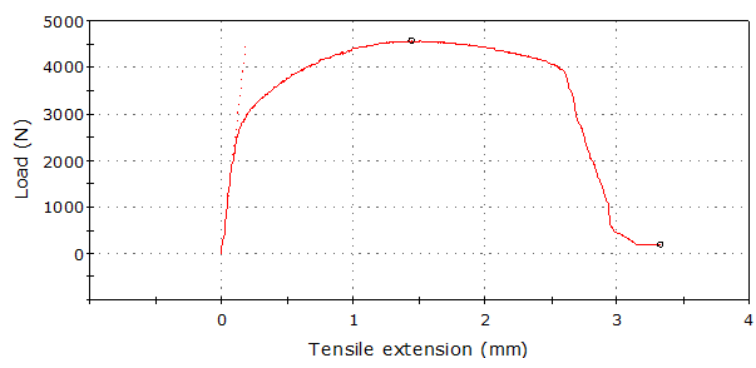

Fig.10. Engineering stress-strain diag. of circular pin profile for $1000 \mathrm{rpm}$

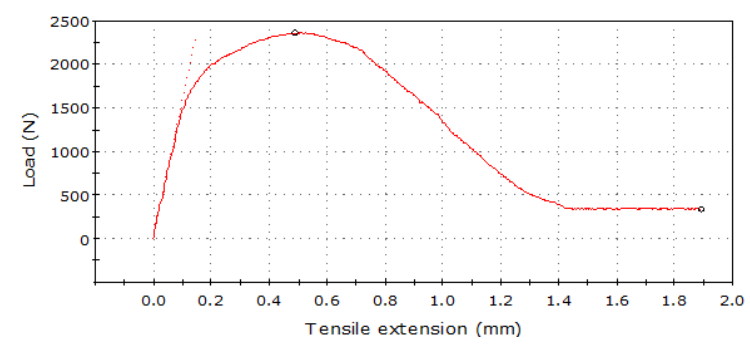

Fig. 11. Engineering stress-strain diagram of circular pin profile for 710rpm

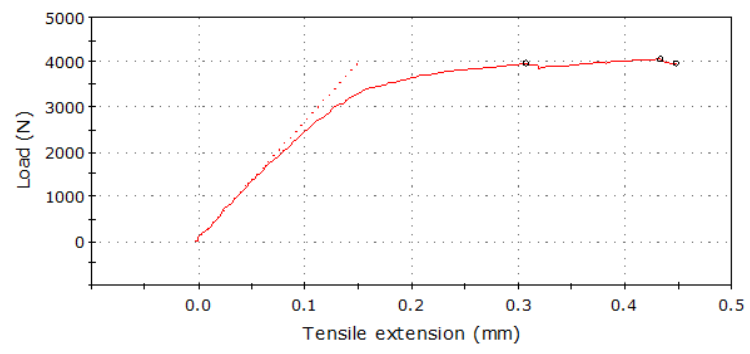

Fig. 12. Engineering stress-strain diagram of square pin profile for $1400 \mathrm{rpm}$

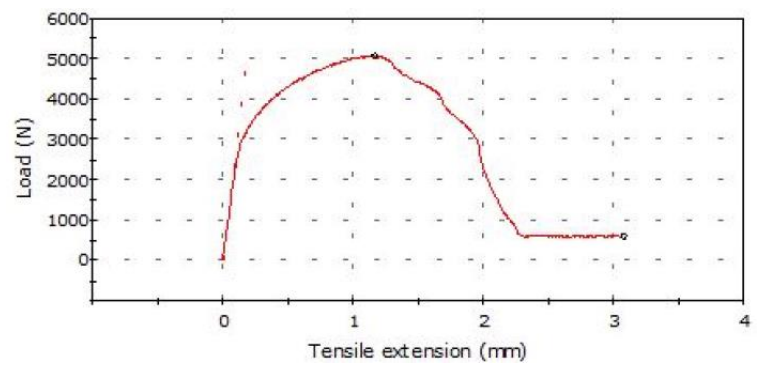

Fig.13. Engineering stress-strain diagram of square pin profile for $1000 \mathrm{rpm}$

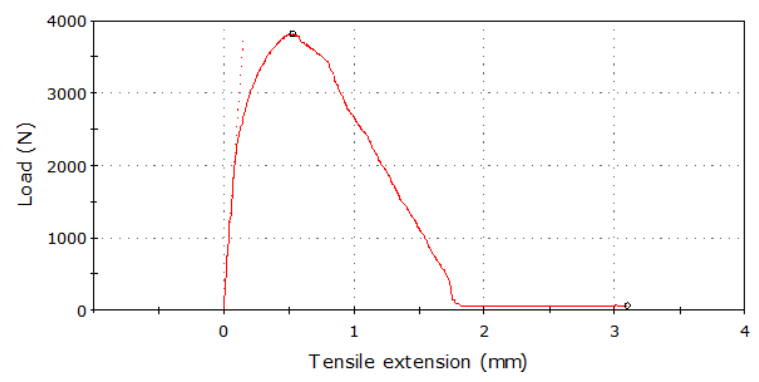

Fig. 14. Engineering stress-strain diagram of square pin profile for 710rpm

With the increase in tool rotational speed, welding speed and tool axial force result in the increase in UTS of the FS welded joints up to a maximum value. The lower rotational speeds, higher welding speeds and lower axial forces (lower heat input condition) produce inadequate heat due to lower friction, which results in poor plastic flow and formation of defects in welded zone(WZ). The defects act as a crack initiation location during tensile test and so, the UTS is lower. The higher rotational speeds, lower welding speeds and higher axial forces (higher heat input condition) produce sufficient heat for metallurgical phenomena such as grain coarsening, solubilisation and coarsening of strengthening precipitates at the $\mathrm{WZ}$, and lowering of dislocation density that decrease the UTS value.

The effect of the tool profile on the tensile strength is examined. Insignificant effect of the tool profile at low welding speed is noticed at the welding speed of $20 \mathrm{~mm} / \mathrm{min}$, the square profile achieves higher strength compared to the circular one. The achieved higher strength using the square profile at 20 
$\mathrm{mm} / \mathrm{min}$ may be due to the produced higher pulses/s than that produced by the circular one.

It can be inferred that the tool profile and welding speed are having influence on tensile properties of the FSW joints. The joints fabricated by square tool profile exhibited superior tensile properties with joint efficiency of $61 \%$ compared to other joints, irrespective of welding speed. Though the tensile strength and hardness values are lower than the base metal, the joint efficiency is acceptable one when compared to conventional fusion welding process with low joint efficiency not exceeding $50 \%$.

\subsection{HARDNESS TEST}

The base has a Vickers hardness of about 130 $\mathrm{HV}$, very high for an alloy of this type. However, the welding process softens the material significantly with the hardness reducing by nearly $50 \%$ around the weld line to about $75 \mathrm{HV}$. The hardness does not seem to have been influenced by the change in pin geometry, probably due to the dominant influence of the tool shoulder on the thermal input during welding.

The width of $6082 \mathrm{Al}$ alloys layer is wider than that of $5083 \mathrm{Al}$ alloy. which was dominant structure of the stir zone showed fine and equiaxed grain structure of $6082 \mathrm{Al}$ alloy and no scars of $5083 \mathrm{Al}$ alloy. The centre region of the stir zone showed macroscopically swirl and vortex-like patterns of each material, microscopically recrystallized $6082 \mathrm{Al}$ alloys and thinly distributed Si particles. A hardness decrease occurs when approaching the TMAZ. The average hardness of the nugget zone (NZ) was found to be significantly lower than the hardness of the base alloy. There is a zone outside the nugget (transition between TMAZ and HAZ)
TABLE V - RESULTS OF HARDNESS TEST OF FSW JOINTS WITH DIFFERENT TOOLS

\begin{tabular}{|c|c|c|}
\hline Sample ID & Square pin tool & Circular Pin Tool \\
\hline $1 \mathrm{~mm}$ & 75.3 & 85.4 \\
\hline $2 \mathrm{~mm}$ & 75 & 85.4 \\
\hline $3 \mathrm{~mm}$ & 74 & 84 \\
\hline $4 \mathrm{~mm}$ & 67.4 & 72.5 \\
\hline $5 \mathrm{~mm}$ & 64.7 & 78.4 \\
\hline $6 \mathrm{~mm}$ & 62.4 & 77.6 \\
\hline $7 \mathrm{~mm}$ & 57.9 & 76.8 \\
\hline $8 \mathrm{~mm}$ & 56.5 & 80.3 \\
\hline $9 \mathrm{~mm}$ & 54.6 & 80.7 \\
\hline $10 \mathrm{~mm}$ & 53.4 & 81 \\
\hline $11 \mathrm{~mm}$ & 53.2 & 81.8 \\
\hline $12 \mathrm{~mm}$ & 53.6 & 82.2 \\
\hline $13 \mathrm{~mm}$ & 55.2 & 81.4 \\
\hline $14 \mathrm{~mm}$ & 70.6 & 79.4 \\
\hline $15 \mathrm{~mm}$ & 80.8 & 59 \\
\hline $16 \mathrm{~mm}$ & 85.1 & 52.1 \\
\hline $17 \mathrm{~mm}$ & 87.9 & 48.6 \\
\hline $18 \mathrm{~mm}$ & 88.1 & 50 \\
\hline $19 \mathrm{~mm}$ & 87.7 & 51.5 \\
\hline $20 \mathrm{~mm}$ & 87 & 56 \\
\hline $21 \mathrm{~mm}$ & 86.5 & 48.7 \\
\hline $22 \mathrm{~mm}$ & 79.6 & 57.1 \\
\hline $23 \mathrm{~mm}$ & 79 & 60.2 \\
\hline $24 \mathrm{~mm}$ & 80.6 & 52.1 \\
\hline $25 \mathrm{~mm}$ & 80.9 & 60.8 \\
\hline
\end{tabular}

which has the lower hardness value. The variation of the micro hardness values in the welded area and parent material is due to the difference between the microstructures of the base alloy and weld zone. Hardness in the dissimilar joints presented the lower values of all parent metals. The hardness in the nugget area is similar for all joints and it is always higher than the values in the transition between the TMAZ and the HAZ. The hardness depends on the precipitate distribution such as $\mathrm{Mg} 2 \mathrm{Si}$. It is likely that the low hardness can be attributed to the resolution of the precipitates during friction stir welding. 
From the results it was observed that the heat input increase during welding results hardness decreasing. Rotating speed is more effective than feed rate in this case. Friction stir welding is caused to decreasing of the displacement density and de-creasing in that cause to decreasing of the micro hardness. In this process tool rotation and feed rate cause to dynamic re-crystallization and dynamic recrystallization cause to new grain giant.

\section{CONCLUSION}

Aluminum alloys 5083 and 6082 were successfully joined by friction sir welding (FSW) and the most favorable welding conditions among those tested were identified. The hardness and tensile properties of the base and weld materials have been characterized and related to their microstructures. The joints properties of friction-stir-welded Al 5083 and Al 6082 alloys were studied with various tool rotating speeds and different tool pin profiles with constant traverse speed $(20 \mathrm{~mm} / \mathrm{min})$. The following conclusions have been derived.

(1) Most favorable friction stir weld parameters over a tested range were established. The choice takes into consideration surface finish, minimum internal defect, and no crack formation and tensile strength, while maximizing tool rotation speed within FSW machine constraints.

(2) The friction stir welding process results in significant grain refinement of the alloy in the weld.

(3) The microstructures of dissimilar formed $\mathrm{Al} 5083$ and Al 6082 alloys joint showed the mixed structures of two materials. The onion ring pattern, which appeared like lamellar structure, was observed in the stir zone. Superior tensile properties of FSW joints were observed, this is due to the formation of fine equiaxed grains and uniformly distributed very fine strengthening precipitates in the weld region.

(4) The microstructure of the stir zone was mainly composed of the material fixed at the retreating side. At the advancing side interface, the grains of the base material show a morphological bending whereas no such characteristic is observed on the retreating side interface. This explains the characteristic sharpness of the advancing side interface than the rather diffuse retreating side interface.

(5) The variations of hardness HV trough the weld depend on the type of material, sheet thickness and welding parameters. The shape of the stirring tool influences the hardness distribution of the FSW joints.

(6) Sound joints were acquired at $20 \mathrm{~mm} / \mathrm{min}$ welding speed when the tool rotating speed was fixed at $1000 \mathrm{rpm}$ for both circular and square tool pin profiles. The dendrite structures, which are characteristic in the base metal (BM), disappeared and showed the dispersed eutectic Si particles in the stir zone (SZ).

(7) The eutectic Si particles were distributed more homogeneously in the SZ at lower welding speeds.

\section{ACKNOWLEDGEMENTS}

The Authors are thankful to VIT University for successful completion of this work.

\section{REFERENCES}

[1] W.M.Thomas, E.D.Nicholas, J.C.Needham, M.G Murch, S.P.Temple, C.J.Dawes, Improvements relating to friction welding. G. B. Patent No.9125978. 8, 1991.

[2] W.M.Thomas, E.D.Nicholas, Friction stir welding for the transportation industries. Mater Des, 18(4-6):pp.269-73, 1997.

[3] ] C.G. Rhodes, M.W. Mahoney, W.H. Bingel, R.A .Spurling, C.C. Bampton, Effects of friction stir welding on microstructure of 7075 aluminum. Scripta Mater ,36(1): pp.69-75, 1997. 
[4] M.W.Mahoney, C.G.Rhodes, J.G.Flintoff, W. H.Bingel, R.A.Spurling, Properties of FSW 7075 T651 Aluminum, Metall. Mater. Trans. A, 29, pp.1955-1964, , 1998.

[5] G. Biallas, G. Braun, C.D. Donne, G. Staniek, W. Kaysser, Mechanicalproperties and corrosion behaviour of friction stir welded 2024T4,Proceedings of the 1st International Symposium "Friction StirWelding”, TWI, CDROM, 1999.

[6] Adamowski, M. Szkodo, Friction Stir Welds (FSW) of aluminium alloy AW6082-T6, Journal of Achievements in Materials and Manufacturing Engineering 20 , pp.403-406, 2007.

[7] M. Vural, A. Ogur, G. Cam, C. Ozarpa, On the friction stir welding of aluminium alloys EN AW 2024-0 and EN AW 5754-H22, Archives ofMaterials Science and Engineering 28/1, pp.4954, (2007).FLEXChip Signal Processor (MC68175/D), Motorola, 1996.

[8] P. Cavaliere, F. Panella, Effect of tool position on the fatigue properties of dissimilar 2024-7075 sheets joined by friction stir welding, Journal of Materials Processing Technology 206, pp.249255,2008.

[9] A. Barcellona, G. Buffa, L. Fratini, D. Palmeri, On microstructural phenomena occurring in friction stir welding of aluminium alloys, Journal of Materials Processing Technology 177 , pp.340343, 2006.

[10] S.T. Amancio-Filho, S. Sheikhi, J.F. dos Santos, C. Bolfarini, Preliminary study on the microstructure and mechanical properties of dissimilar friction stir welds in aircraft aluminium alloys 2024-T351 and6056-T4, Journal of Materials Processing Technology 206, pp.132$142,2008$.

[11] J.A. Esparza, W.C. Davis, E.A. Trillo, L.E. Murr, Friction-stir welding of magnesium alloy AZ31B, Journal of Materials Science Letters 21, pp.917-920, 2002.

[12] B.M. Darras, M.K. Khraisheh, F.K. Abu-Farha, M.A. Omar, Friction stir processing of commercial AZ31 magnesium alloy, Journal of Materials Processing Technology 191, pp.77-81, 2007.

[13] T.J. Lienert, W.L. Stellwag, B.B. Grimmett, R.W. Warke, Friction Stir Welding Studies on Mild Steel, Welding Journal, Research Supplement 82/1, pp.1-9, 2003
[14] A.P. Reynolds, W. Tang, T. Gnaupel-Herold, H. Prask, Structure, properties, and residual stress of 304L stainless steel friction stir welds, Scripta Materialia 48, pp.1289-1294, 2003.

[15] H. Uzun, C.D. Donne, A. Argagnotto, T. Ghidini, C. Gambaro, Frictionstir welding of dissimilar Al 6013-T4 To X5CrNi18-10 stainless steel, Materials and Design 26, pp.41-462005.

[16] K. Kimapong, T. Watanabe, Friction Stir Welding of aluminum alloy to steel, Welding Journal 83/10 , pp.277-282, 2004.

[17] J. Ouyang, E. Yarrapareddy, R. Kovacevic, Microstructural evolution in the friction stir welded 6061aluminum alloy (T6-temper condition) to copper, Journal of Materials Processing Technology 172, pp.110-122, 2006.

[18] A.C. Somasekharan, L.E. Murr, Microstructures in friction-stir welded dissimilar magnesium alloys and magnesium alloys to 6061-T6 aluminum alloy, Materials Characterization 52, pp.49-64, 2004.

[19] W.B. Lee, S.B. Jung, The joint properties of copper by friction stir welding, Materials Letters 58, pp.1041-1046, 2004.

[20] G.M. Xie, Z.Y. Maa, L. Geng, Development of a fine-grained microstructure and the properties of a nugget zone in friction stir welded pure copper, Scripta Materialia 57, pp.73-76, 2007.

[21] T. Sakthivel, J. Mukhopadhyay, Microstructure and mechanical properties of friction stir welded copper, Journal of Materials Science 42, pp.81268129, 2007.

[22] H.S. Park, T. Kimura, T. Murakamic, Y. Naganod, K. Nakata, M. Ushio, Microstructures and mechanical properties of friction stir welds of 60\% Cu-40\% Zn copper alloy, Materials Science and Engineering A 371, pp.160-169, 2004.

[23] C. Meran, The joint properties of brass plates by friction stir welding, Materials and Design 27, pp.719-726, 2006.

[24] C.G. Andersson, R.E. Andrews, B.G.I. Dance, M.J. Russell, E.J. Olden, R.M. Samderson, A comparison of copper canister fabrication by the electron beam and friction stir processes, Proceedings of the $2^{\text {nd }}$ International Symposium "Friction Stir Welding", Gothenburg,CD-ROM, 2000.

[25] Mishra R.M., Mahoney M.W. Friction stir welding \& processing, ASM International, pp.360, 2007. 
[26] Aydın H., Bayram A., Agah U., Akay K. S..Tensile properties of friction stir welded joints of 2024 aluminum alloys indifferent heat-treatedstate, Materials and Design, Vol.30, pp. 22112221, 2009.

[27] Cavaliere P., Squillace A., Panella F., Effect of welding parameters on mechanical \& microstructural properties of AA6082 joints produced by friction stir welding, Journal of Materials Processing Technology, Vol.200, No.1-3, pp.364-372, 2008.

[28] Moreira P. M. G. P., Santos T. Tavares S. M. O, Richter-Trummer V., Mechanical and metallurgical characterization of friction stir welding joints of AA6061-T6 with AA6082-T6, Materials and Design, Vol. 30, pp.180-187, 2009.

[29] Cavaliere P., Santis A. De., Panella F., Squillace A., Effects of welding parameters on mechanical and microstructural properties of dissimilar AA6082-AA2024 joints produced by friction stir welding, Materials and Design, Vol. 30, pp. 609616, 2009.

[30] Lee W.B., Yeon Y.M., Jung S.B., Evaluation of the microstructure and mechanical properties of friction stir welded 6005 aluminum alloy, Material Science \& Technology, Vol.19, No.11, pp.1513-1518, 2003.

[31] Simar A., Brechet Y., Meester B. de., Denquin A., Pardoen T., Microstructure, local and global mechanical properties of friction stir welds in aluminium alloy 6005A-T6. Material Science \& Engineering, Vol. 486, No.1-2, pp. 85-95, 2008.

[32] Peel M.J., Steuwer A., Withers P.J., Dickerson T., Shi Q., Shercliff H., Dissimilar friction stir welds in AA5083-AA6082, 2006.

[33] Lim S., Kim S., Lee C.G., Kim S.J., Tensile behavior of friction-stir-welded Al 6061- T651, Metallurgical and Material Transactions A, Vol. 35, No.9, pp. 2829-2835, 2004.

[34] Ren S.R., Ma Z.Y., Chen L.Q., Effect of welding parameters on tensile properties and fracture behavior of friction stir welded $\mathrm{Al}-\mathrm{Mg}-\mathrm{Si}$ alloy, Scripta Materialia,Vol.56, No.1, pp.69-72, 2007.

[35] Senthil Kumaran S., Muthukumaran S., Vinodh S., Experimental and numerical investigation of weld joints produced by friction welding of tube to tube plate using an external tool, International Journal of Engineering, Science and Technology, Vol. 2, No.2 pp.109-117, 2010. 
دراسة تأثير اللحام بالإحتكاك الدوراني على الخصائص الميكانيكية لوصلة من معدنيين مختلفين

$$
\text { مدرسة الميكانيكا والبناء/جامعة فيلور التقنية، فيلور، الهند }
$$

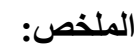

إن اللحام بالإحتكاك الدور اني لهو طريقة مبتكرة في وصل السبائك المعدنية وقد أوجدت بديلا تقنيا يستخدم في وصل السبائك التي يصعب لحامها بالطرق التقليدية. وقد ظهر هذا التطبيق في صناعات مختلفة متل صناعات الطائرات والسكك الحديدية والسيارات وكذلك الصناعات البحرية وذلك في وصل سبائك الألومونيوم و الماغنسيوم و النحاس. وتلعب سرعة دوران وسرعة اللحام والقوة المحورية وزاوية الهجوم دورا أساسيا في جودة اللحام.

إن الهذف من هذا البحث هو در اسة التأثير ات المختلفة من سرعات اللحام وشكل أداة اللحام على جودة وصلة من سبيكتين AA6082-Al 5083 و هذه الخامة قد وجدت قبو لا واسعا في الصناعات التي تتطلب خفة الوزن مع المتانة العالية. وقد استخدمت في هذا البحث أداة لحام دائرية واخرى مربعة. وتظهر النتائج المستخلصة إختلاف الإجهاد كدالة في الإنفعال وسر عة وشكل الأداة على قوة الثد والإسنطالة. 